\title{
Household Waste Generating Factors and Composition Study for Effective Management in Gorkha Municipality of Nepal
}

\author{
Bijan Maskey ${ }^{1} \&$ Mrinila Singh ${ }^{2}$ \\ ${ }^{1}$ Graduate School for International Development and Cooperation, Hiroshima University, Higashi-Hiroshima, \\ Hiroshima, Japan \\ ${ }^{2}$ Higashi-Hiroshima, Hiroshima, Japan \\ Correspondence: Bijan Maskey, Graduate School for International Development and Cooperation, Hiroshima \\ University, 1-5-1 Kagamiyama, Higashi-Hiroshima, Hiroshima 739-8529, Japan. Tel: 81-80-4558-3834. E-mail: \\ mr_bijan@hotmail.com
}

Received: September 21, 2017

Accepted: October 19, 2017

Online Published: November 29, 2017

doi:10.5539/jsd.v10n6p169

URL: https://doi.org/10.5539/jsd.v10n6p169

\begin{abstract}
Municipal solid waste is a growing concern in cities of developing countries and households are the main contributor. Lack of reliable data sources remain one of the major drawbacks for deciding on effective waste management option. The study area Gorkha municipality is selected because it is one of the highly under-researched and least resource intensive municipalities in Nepal. However, continued growth in municipal waste if left unattended will only intensify the problem and thus demands proactive action. Therefore, the objective of this study is to analyze waste composition and to evaluate the socioeconomic factors impacting household waste generation for effective management. Using stratified sampling method, 401 households were selected from all 15 municipal wards. Socioeconomic factors impacting household waste generation were assessed using Ordinary Least Square regression model. The rate of household waste generation in Gorkha municipality is found to be $0.24 \mathrm{~kg} / \mathrm{capita} /$ day and estimated total household waste generation of 9.4 tonnes/day. Household size and income are found to have positive impact on waste generation, both statistically significant at $1 \%$ and thus can be important indicators to forecast solid waste generation trend. Household waste composition was $47.25 \%$ organic waste, $37.52 \%$ recyclable waste that comprised of $10.38 \%$ paper and paper products, $9.88 \%$ glass, $6.92 \%$ metal, $5.39 \%$ plastic, $3.57 \%$ textile and $1.38 \%$ rubber and leather, and rest $15.23 \%$ other waste. Organic waste has the highest share and if not managed properly, creates serious health and environmental hazards. It could be managed efficiently by composting at household and local government level.
\end{abstract}

Keywords: household waste, waste composition, waste generation, waste management

\section{Introduction}

Municipal solid waste (MSW) is a mounting problem for cities in developing countries. It is increasing faster than the urbanization rate (from 2002-2012, urban population increased by $3.45 \%$ but waste generation by $87.5 \%$ ) and is expected to rise further, especially in lower and lower middle-income countries (Hoornweg \& Bhada-Tata, 2012). Although the local governments in developing countries spend up to $50 \%$ of municipal budget for waste collection and disposal, its management is far from satisfactory (Aleluia \& Ferrão, 2016). Rapid urbanization, low political priority, poor allocation of resources, limited awareness, operational deficiencies in coordinating activities of various actors involved, and use of inappropriate technologies leading to inefficient use of time and resources are the reasons for inadequate service delivery in low income urban areas (Pfammatter \& Schertenleib, 1996). Uncontrolled disposal of waste results in surface and groundwater contamination through leachate; soil pollution through direct waste contact or contaminated liquid waste percolation; air pollution through waste burning; spreading of diseases by vectors like birds, insects, and rodents; foul odor; and release of methane (Zorpas, Lasaridi, Voukkali, Loizia, \& Chroni, 2015).

Nepal, one of the least developed countries in South Asia is no exception to such situation. It is inhabited by 26.5 million people with an average annual population growth rate of $1.35 \%$ from 2001 to 2011 (Central Bureau of Statistics [CBS], 2014b). Not just the rapid population growth in urban areas (Solid Waste Management and Resource Mobilization Center [SWMRMC], 2008) but increase in Gross Domestic Product (GDP) over the years from US\$ 9.04 billion in 2006 to US\$21.14 billion in 2016 (The World Bank, 2017) 
could have also contributed to growing municipal waste as number of studies have shown positive correlation between the two (Aleluia \& Ferrão, 2016; Kawai \& Tasaki, 2016; Palanivel \& Sulaiman, 2014; Senzige, Makinde, Njau, \& Nkansah-Gyeke, 2014). Municipalities and community groups in Nepal are mainly characterized by having limited access to information, especially on improving waste management system and using waste in an economically productive way (Practical Action Nepal, 2008). Within the existing solid waste management (SWM) scenario, there is no proper and effective waste collection system and only limited recycling and composting activities are practiced all over Nepal (Padeco Co. Ltd. \& Consultants, 2010). Haphazard depositing and burning piles of waste along the roads and riversides is a common sight, causing health hazards and environmental problems in-situ as well as downstream (Pokhrel \& Viraraghavan, 2005). Thus, it is only a matter of time that waste generation will be multiplied and will further intensify the problem if not managed effectively well ahead of time.

Before deciding upon the optimal waste recovery and management options, it is important to know the current status of waste related issues. The primary step is to understand how much and what kind of waste is generated in order to decide the most effective strategy for its management (Adeniran, Nubi, \& Adelopo, 2017; Aleluia \& Ferrão, 2016; Armijo de Vega, Ojeda Benítez, \& Ramírez Barreto, 2008; Edjabou et al., 2015; Gallardo, Edo-Alcón, Carlos, \& Renau, 2016; Khan, Kumar, \& Samadder, 2016; Miezah, Obiri-Danso, Kádár, Fei-Baffoe, \& Mensah, 2015; Trang, Dong, Toan, Hanh, \& Thu, 2017). This study attempted to make a move in this direction by analyzing generation and composition of household $(\mathrm{HH})$ waste in Gorkha municipality. In developing countries, about 55-80\% of MSW are known to be generated by HHs (Miezah et al., 2015). In Nepal too, it is assumed that HHs account for on average $75 \%$ of total municipal waste generation (SWMRMC, 2004). In addition, this study also analyzes HHs' socioeconomic factors impacting waste generation. Waste generation is heterogeneous (Miezah et al., 2015) and are highly dependent on socioeconomic status of the population (Sankoh, Yan, \& Conteh, 2012). Socioeconomic factors enable people to access resources required to improve their living standard. It includes material goods, money, power, networks, healthcare, leisure time or educational opportunities. The combination of these factors determine how a social hierarchy is structured, one's standing within this hierarchy and most often one's opportunities as well (Senzige et al., 2014). Although the characteristics among urban areas of developing countries are quiet common, waste management tactics should be context specific, locally sensitive, critical, creative, and owned by the community of concern; as their specific circumstances may be significantly different (Aleluia \& Ferrão, 2016; Marshall \& Farahbakhsh, 2013). Thus, this study is expected to highlight socioeconomic factors impacting waste generation and assesses waste composition in Gorkha municipality, based on its unique characteristics that is expected to contribute in decision-making by the stakeholders, especially at the local municipality level.

\section{Material and Methods}

\subsection{Study Area}

This study was conducted in Gorkha municipality (Figure 1) that lies in the Mid-Hills of Western development region of Nepal, between $27^{\circ} 56^{\prime} 03^{\prime \prime}$ to $28^{\circ} 13^{\prime}$ ' $07^{\prime \prime}$ north latitude and $84.23^{\circ}$ to $84.38^{\circ}$ east longitude. It occupies an area of 83.55 square kilometers and has an average temperature of $25^{\circ} \mathrm{C}$ with an average annual rainfall of 149.2 millimeter. It is divided into 15 wards, the smallest administrative unit of the country and has a population of 39,172 inhabitants (Gorkha Municipality Office, 2015). It has a population density of 539 persons per $\mathrm{km}^{2}$, which is lower compared to national urban population density of 1,345 persons per $\mathrm{km}^{2}$ and average $\mathrm{HH}$ size is 3.69, also lower compared to national average of 4.21 (CBS, 2014c).

\subsection{Status of Municipal Solid Waste in Gorkha Municipality}

Most of the SWM related studies in Nepal are concentrated in Kathmandu valley in either one or all of its three districts: Kathmandu, Lalitpur and Bhaktapur (Baker, 1997; Devkota, Watanabe, \& Dangol, 2004; Duwal, 2015; Japan International Cooperation Agency [JICA], 2005; Pokhrel \& Viraraghavan, 2005; M. E. I. Shrestha, Sartohadi, Ridwan, \& Hizbaron, 2014; Society for Environment and Economic Development Nepal [SEED Nepal], 2009). Among these, many are still confined within Kathmandu district or to be precise Kathmandu Metropolitan City (KMC), the capital city of Nepal (Alam, Chowdhury, Hasan, Karanjit, \& Shrestha, 2008; Dangi, Pretz, Urynowicz, Gerow, \& Reddy, 2011; Premakumara, 2013; Ranabhat, 2015; S. L. Shrestha, 2015; Singh, Yabar, Mizunoya, Higano, \& Rakwal, 2014; Thapa, 1998). While it is understandable that waste problem will be more severe in the most urbanized areas, other municipalities are also equally affected in their own right. However, only few studies have focused on some or all of the then 58 municipalities of Nepal (Asian Development Bank [ADB], 2013; Practical Action Nepal, 2008; SWMRMC, 
2004, 2008).

Gorkha municipality is selected because it represents one such municipality that does not fall under the priority of SWM researchers or implementers, but growing amount of waste nonetheless demands proactive action. It is one of the least resource intensive municipalities in Nepal. When it comes to having human resources in waste management, only one staff is available to serve 5,392 inhabitants and daily cleaning service covered only $0.4 \mathrm{~km}$ of the street in 2003 that increased to just $2.5 \mathrm{~km}$ in 2008 (SWMRMC, 2004, 2008). It provides waste collection service only on few of the municipal wards and have only one tractor to collect and manage municipal waste. The collected waste is disposed openly in designated dumping site within the municipality but harmful waste such as medical waste, batteries and light bulbs are also dumped together with other waste. At management level, there is lack of cooperation at different levels with no integrated approach. At implementation level, there is no landfill site; inadequate human resources; no technical knowhow; lack of transportation; lack of reuse, recycling and composting; political problems; and lack of community participation (ADB, 2013; SWMRMC, 2004, 2008).

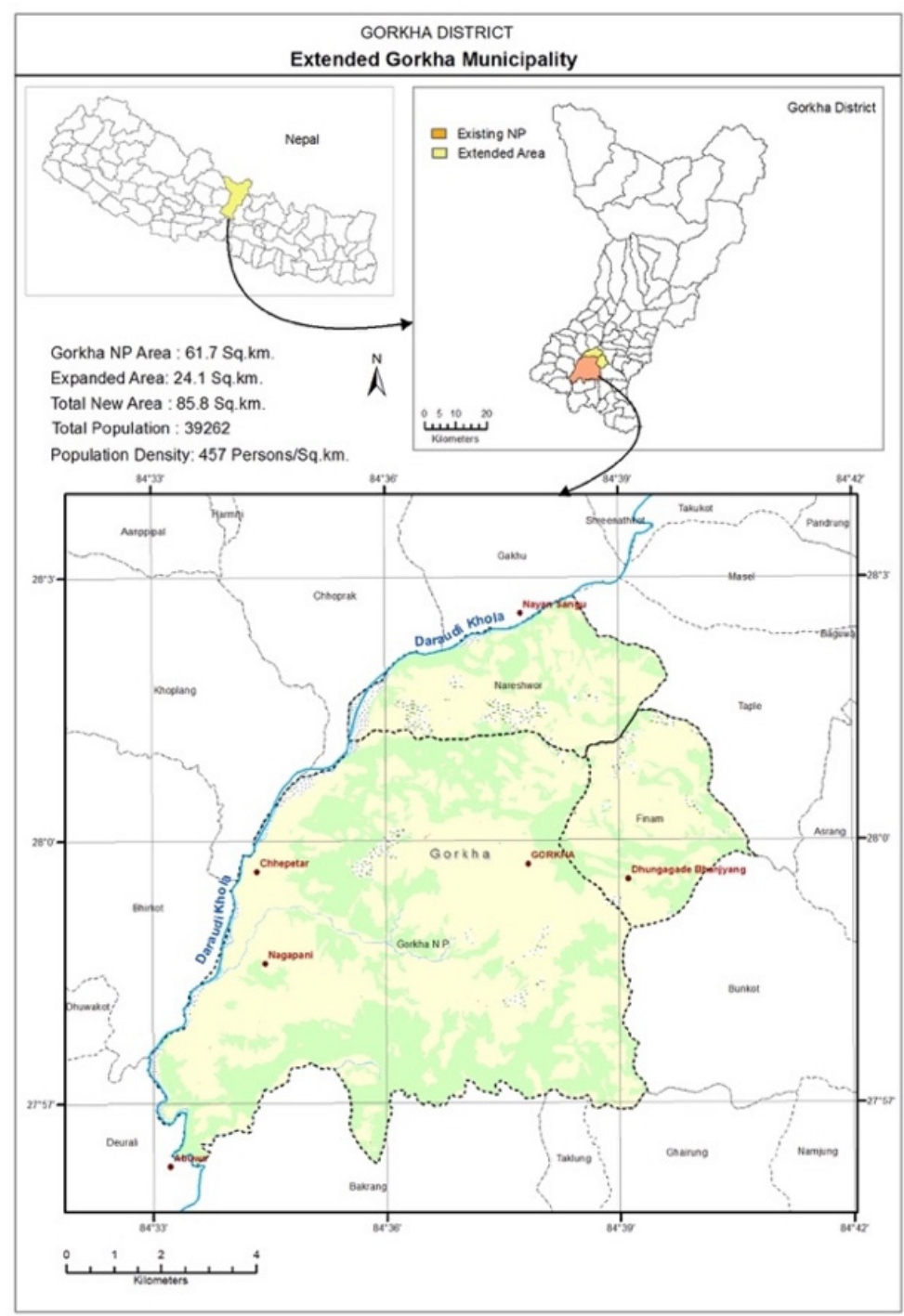

Figure 1. Map of Gorkha municipality

Source: Local Governance and Community Development Programme [LGCDP], (2016)

There are some studies (ADB, 2013; SWMRMC, 2004, 2008) conducted in all the then 58 municipalities of 
Nepal and the amount of waste generation and composition in Gorkha municipality compared with national average is presented in Table 1 and Table 2 respectively. These studies however considered only one day of waste generation data and did not cover all the municipal wards. Furthermore, due to lack of consistent scientific methods and different assumptions made to quantify waste generated from different sources, the findings of these studies are inconsistent. As such, there is no consistent trend of increase in per capita waste generation, and total municipal waste generation and collection. Thus, this leads us to question the very authenticity of such data and whether the concerned stakeholders should rely on it for making decisions. Unfortunately, this is a common problem for many developing countries where either statistics are lacking or are inconsistent because of data sources that cannot be validated and are sometimes based on assumptions rather than scientific measurements (Miezah et al., 2015). In 2012, organic or biodegradable waste (48.2\%) accounted for the highest amount of waste generation followed by paper $(20.4 \%)$, plastic $(12.3 \%)$, glass $(2.7 \%)$, metal $(0.8 \%)$ and textile $(0.5 \%)$, while the rest accounted for other types of waste. Except for paper, plastic and other types of waste; composition of all other waste is lower than national average. Compared to 2003, the amount of paper and plastic waste seem to have increased but nonetheless organic waste still accounts for the largest share compared to all other waste types (ADB, 2013; SWMRMC, 2004, 2008).

Table 1. Comparison of waste generation of Gorkha municipality with national municipal average

\begin{tabular}{lllllll}
\hline \multirow{2}{*}{ Variables } & 2003 & & 2008 & \multicolumn{3}{c}{2012} \\
\cline { 2 - 7 } & $\begin{array}{l}\text { National } \\
\text { Average }\end{array}$ & Gorkha & $\begin{array}{l}\text { National } \\
\text { Average }\end{array}$ & Gorkha & $\begin{array}{l}\text { National } \\
\text { Average }\end{array}$ & Gorkha \\
\hline $\begin{array}{l}\text { HH waste } \\
\text { (kg/capita/day) }\end{array}$ & 0.25 & 0.26 & 0.27 & $0.30^{*}$ & 0.15 & 0.14 \\
$\begin{array}{l}\text { Total municipal waste generation } \\
\text { (tonnes/day) }\end{array}$ & 23.60 & 9.35 & 19.89 & 8.10 & 24.74 & 6.60 \\
$\begin{array}{l}\text { Total municipal waste collection } \\
\text { (tonne/day) }\end{array}$ & 11.79 & 1.50 & 13.05 & 4.86 & 18.27 & 2.00 \\
\begin{tabular}{l} 
Collection efficiency (\%) \\
\hline
\end{tabular} & 42.35 & 16.05 & 65.61 & 60.00 & 62.30 & 30.30 \\
\hline
\end{tabular}

Note. * per capita municipal waste generation.

Source: ADB (2013); SWMRMC (2004, 2008)

Table 2. Comparison of waste composition of Gorkha municipality with national municipal average

\begin{tabular}{|c|c|c|c|c|c|c|}
\hline \multirow[b]{2}{*}{ Waste Type } & \multicolumn{2}{|l|}{2003} & \multicolumn{2}{|l|}{2008} & \multicolumn{2}{|l|}{2012} \\
\hline & $\begin{array}{l}\text { National } \\
\text { Average (\%) }\end{array}$ & $\begin{array}{l}\text { Gorkha } \\
(\%)\end{array}$ & $\begin{array}{l}\text { National } \\
\text { Average (\%) }\end{array}$ & $\begin{array}{l}\text { Gorkha } \\
(\%)\end{array}$ & $\begin{array}{l}\text { National } \\
\text { Average (\%) }\end{array}$ & $\begin{array}{l}\text { Gorkha } \\
(\%)\end{array}$ \\
\hline Organic & 62.0 & 46.9 & 61.2 & 69.6 & 66.4 & 48.2 \\
\hline Plastic & 7.3 & 2.1 & 8.4 & 9.8 & 12.0 & 12.3 \\
\hline $\begin{array}{l}\text { Paper and paper } \\
\text { products }\end{array}$ & 8.2 & 19.2 & 8.6 & 5.0 & 9.0 & 20.4 \\
\hline Glass & 2.4 & 5.6 & 4.1 & 5.2 & 3.1 & 2.7 \\
\hline Metal & 1.2 & 4.2 & 1.3 & 0.0 & 1.9 & 0.8 \\
\hline Textile & 1.9 & 0.0 & 1.7 & 0.1 & 2.2 & 0.5 \\
\hline $\begin{array}{l}\text { Rubber and } \\
\text { Leather }\end{array}$ & 0.9 & 4.9 & 1.1 & 0.8 & 1.1 & 0.0 \\
\hline Others & 16.1 & 17.2 & 13.5 & 9.6 & 4.5 & 15.1 \\
\hline
\end{tabular}




\subsection{Sampling Procedure}

This study relies on primary data gathered from individual HH survey using semi-structured questionnaire, researcher's observation and key-informant interview. Based on the latest document available in the municipality office, there are 9,236 $\mathrm{HHs}$ in all 15 wards. Data was collected using stratified sampling method by taking municipal ward as a stratum. Sample size was decided based on simplified formula for proportions by Yamane (1967). According to Yamane, at 95\% confidence level,

$$
n=N /\left\{1+N(e)^{2}\right\}
$$

where;

$n$ : Sample size

$N$ : Population size

$e$ : Level of precision

Using this formula, at $95 \%$ confidence level and $\pm 5 \%$ precision level, required sample was $384 \mathrm{HHs}$, which was proportionally divided among all 15 wards. As a precaution to make up for the shortcomings of non-response and/or partly filled questionnaire, $10 \%$ of additional HHs were selected from each ward and final sample of 401 HHs was considered for this study (Table 3). The questionnaire was tested before finalizing for collecting data that took place from November to December 2015. Although the local seasonal variation of waste generation should be reflected (Dahlén \& Lagerkvist, 2008); study conducted by JICA (2005) found no significant differences in per capita waste generation between dry and wet seasons by the HHs in KMC, Lalitpur Sub-Metropolitan City (LSMC) and Madhyapur Thimi municipality of Nepal. Therefore, this study does not consider waste generation in different seasons. Nevertheless, this study period reflects the transition phase from autumn to winter.

Table 3. Sample selection from all wards of Gorkha municipality

\begin{tabular}{llcc}
\hline Ward no. & $\begin{array}{l}\text { No. of } \\
\text { HHs }\end{array}$ & $\begin{array}{c}\text { Required sample size } \\
( \pm 5 \% \text { precision level at } 95 \% \text { confidence level })\end{array}$ & Final sample for this study \\
\hline Ward 1 & 518 & 21 & 22 \\
Ward 2 & 538 & 22 & 22 \\
Ward 3 & 594 & 25 & 25 \\
Ward 4 & 786 & 33 & 35 \\
Ward 5 & 469 & 19 & 21 \\
Ward 6 & 678 & 28 & 30 \\
Ward 7 & 450 & 19 & 19 \\
Ward 8 & 910 & 38 & 40 \\
Ward 9 & 760 & 32 & 33 \\
Ward 10 & 653 & 27 & 29 \\
Ward 11 & 723 & 30 & 32 \\
Ward 12 & 456 & 19 & 20 \\
Ward 13 & 430 & 18 & 19 \\
Ward 14 & 693 & 29 & 31 \\
Ward 15 & 578 & 24 & 23 \\
\hline Total & 9236 & 384 & 401 \\
\hline
\end{tabular}

Each HH was given two disposable containers (polythene bags), which was numbered and was asked to segregate organic (food/kitchen waste including wet paper, leaves, tree branches, wood waste, and agricultural waste) and other waste types (all others including dry paper) for a period of one week, after providing proper training on waste sorting. It is assumed that weekly data (Dahlén \& Lagerkvist, 2008; Gu et al., 2015) and 
inclusion of all 15 wards provide much more robust output than one day data covering only few selected municipality wards which previous studies (ADB, 2013; SWMRMC, 2004, 2008) relied on. To determine the amount and composition of $\mathrm{HH}$ waste, collecting waste at generation site and directly hand sorting method was adopted, which is known to be the most accurate method for reliable data collection (Gu et al., 2015). With the help of municipal employees, segregated wastes were collected and transferred through municipal tractor to the disposal site for re-segregating and weighing manually all waste types for more meticulous analysis. Different method of waste categorization makes analysis incomparable, which is true even for nationally aggregated figures that may overlook significant differences among cities in the same country (Aleluia \& Ferrão, 2016). Using similar waste components for classification and usually not more than 10 categories is recommended to reduce risk of misunderstanding and be useful for comparison (Dahlén \& Lagerkvist, 2008). Thus, following most recent study by ADB (2013), this study categorizes waste into 8 types: organic, metal, paper and paper products, plastic, glass, textile, rubber and leather, and others.

After learning that the local government had promoted $\mathrm{HH}$ composting by distributing subsidized compost bins to $300 \mathrm{HHs}$ over the years along with providing one day training and awareness program, a follow-up research was conducted from February to March 2016 to understand its status. Due to poor record keeping, the municipality only had information of 174 recipients out of which 149 HHs (86\%) were randomly selected and visited to investigate the usage rate of compost bin.

\subsection{Identification of Factors Influencing Waste Generation}

In order to select relevant factors that influence waste generation for this study, number of related literatures were reviewed in addition to referring to the characteristics of the study area itself. Significant factors that affect waste generation from those relevant studies are considered in this study. The referred literatures are conducted in different parts of the world, thus reflecting unique characteristics of each of these places. Variables used in this study and its description and measurement are summarized in Table 4.

Table 4. Description and measurement of selected variables of households on waste generation

\begin{tabular}{lll}
\hline Variables & Description & Unit of measure \\
\hline HH waste & Solid waste generation by the HH & Kg/day \\
Gender & Gender of household head $(\mathrm{HHH})$ & 1 = Male; 0 = Female \\
Age & Age of HHH & Years \\
Education & Educational attainment of HHH & Years \\
Occupation & Occupation of HHH & Employed = 1; Unemployed $=0$ \\
HH size & Total number of family members currently & Number of individuals \\
& residing & \\
House ownership & House ownership & $1=$ Owned; $0=$ Rented \\
Income & Total monthly income of HH & Nepalese Rupee \\
\hline
\end{tabular}

\subsubsection{Gender}

Men and women might have different attitude towards environmental problem and thus a gender-sensitive approach in waste management can boost effectiveness in resource allocation and avoid unnecessary costs (Organization for Security and Co-operation in Europe [OSCE], 2009). Kayode and Omole (2011) found adverse impact of sex on waste generation in Nigeria. According to Dalen and Halvorsen (2011), there are studies emphasizing women generating more waste, and yet many others do not find significant gender effects in waste generation because it is the accumulated result of all HH members' behavior. In Nepal, female-headed HHs have increased from $14.87 \%$ in 2001 to $25.73 \%$ in 2011 (CBS, 2014a). Since usually women are responsible for management of HH work including those related to waste than men (OSCE, 2009), it would be interesting to see how female-headed HHs impacts waste generation compared to men.

\subsubsection{Age}

Depending on age, one can have a very different waste-generating behavior. In Czech Republic, the lowest level of MSW generation was by children and teenagers, and the highest was by people reaching towards the end of their working career or around the time of their retirement because of various activities (reconstruction of home, 
replacement of HH goods, sorting and discarding one's belongings accumulated during previous decades, etc.) which lead to generating large amounts of waste (Soukopová, Struk, \& Hřebíček, 2016). Study by Kayode and Omole, (2011) found adverse impact of age in Nigeria; while Maskey, Maharjan, and Singh (2016) found age of $\mathrm{HHH}$ to have significant positive relation with waste generation in the Philippines.

\subsubsection{Education}

$\mathrm{Gu}$ et al. (2015) found education level of HH's daily manager in China to have negative impact on HH waste generation. OECD (2014) too found education to have negative relation on per capita generation of solid waste. On the other hand, Kayode and Omole (2011) found positive influence of educational status. Sujauddin, Huda, and Hoque (2008) also showed average level of education of family members in Bangladesh to have significant positive impact. Usually higher education is related with high level of awareness on environmental issues, but sometimes it can have opposite relation because of the cumulative nature of education that increases with the new number of graduates every year, but environmental awareness (such as impact of higher waste generation) does not increase at the same pace (Oribe-Garcia, Kamara-Esteban, Martin, Macarulla-Arenaza, \& Alonso-Vicario, 2015).

\subsubsection{Occupation}

Studies by Maskey et al. (2016) in the Philippines; Kayode and Omole (2011) in Nigeria and Sankoh et al. (2012) in Sierra Leone showed employment status to have positive impact in generating more waste. Bandara, Hettiaratchi, Wirasinghe, and Pilapiiya (2007) in Sri Lanka revealed that number of employed people in HH contributed in increasing waste amount. In Turkey, Keser, Duzgun, and Aksoy (2012) measured unemployment rate as it signifies family's inability to generate higher income and found it to have significant negative impact on waste generation. With unemployed members, purchasing power of HHs diminishes and so does their consumption, which will result in lesser HH waste generation (Oribe-Garcia et al., 2015). But sometimes employment rate can have negative effect on $\mathrm{HH}$ waste generation too because with employment, HHs will have higher income which they might use for dining outside rather than cooking at home, thus decreasing the intensity of human activities at home and generating less waste (Xu et al., 2016).

\subsubsection{Household Size}

Studies by Afroz, Hanaki, and Tudin (2011); Khan et al. (2016); Maskey et al. (2016) Sankoh et al. (2012); Senzige et al. (2014); Sujauddin et al. (2008); Suthar and Singh (2015); and Trang et al. (2017) showed HH size to have positive impact on generating more waste. Increase in $\mathrm{HH}$ size will lead to more waste generation but at a decreasing rate (OECD, 2014). While it is apparent for more members of a $\mathrm{HH}$ to generate more waste, the phenomena of 'group living' and 'common consumption' can sometimes saturate the amount of waste being generated as number of generators increase (Gu et al., 2015; Ojeda-Benítez, Vega, \& Marquez-Montenegro, 2008). Many studies have also supported HH size to have opposing effect on waste generation (Bandara et al., 2007; Irwan, Basri, \& Watanabe, 2012; Kayode \& Omole, 2011; Miezah et al., 2015; Ogwueleka, 2013; Qu et al., 2009). Large family are at an advantage when it comes to intensive utilization of materials such as food, paper and plastic, etc.; thus decreasing per capita waste generation compared to the small family (Xu et al., 2016).

\subsubsection{House Ownership}

Sankoh et al. (2012) showed number of rooms to have positive impact in generating more waste. Lebersorger and Beigl (2011) found percentage of buildings with solid fuel heating as one of the important factors influencing MSW. Kayode and Omole (2011) found positive influence of type of building on waste generation. While all these studies included certain feature of dwelling, this study assesses how people living in their own house impacts waste generation compared to tenants. During the test survey, it was observed that those who live in their own house are more caring about their surrounding and thus are more cautious in keeping their surrounding clean, which might impact on their waste generating behavior. Conversely, tenants might not care as much about their surrounding because they do not have a strong sense of belonging to that place and that they are there only temporarily. Although most HHs live in their own house, HHs residing in rented houses have been increasing in urban areas of Nepal (CBS, 2014a).

\subsubsection{Income}

Studies by Afroz et al. (2011); Gu et al. (2015); Irwan et al. (2012); Kayode and Omole (2011); Maskey et al. (2016); Ogwueleka (2013); Sankoh et al. (2012) and Sujauddin et al. (2008) showed monthly income to have positive impact on waste generation. With higher income, it is expected to increase demand for commodity products, the consumption of which will ultimately produce more waste. Bandara et al. (2007) explained the relatively high food consumption trends of higher income groups increased purchases of packaged products and 
reading material that will result in higher waste generation. Contrarily, Qu et al. (2009) in China found family income to have negative impact on waste generation. Trang et al. (2017) clarified those having higher income dine outside more frequently than cooking at home, whether it be at work or for leisure; thus, generating less waste. Another study in China by Xu et al. (2016) explained per capita HH waste and income cannot be simply linearly correlated. Often times, in early stages of urbanization, growth in family income leads to material consumption, which increases waste amount. However, as urbanization level matures, it will have gradual weakening positive effect and in an advanced stage, growth of income will barely have any positive effect. Sometimes it even prevents HH waste generation because income growth encourages environmental awareness among urbanites to certain extent.

\subsection{Empirical Model}

This study uses Ordinary Least Square (OLS) as multiple linear regression model. It is widely used because of its simplicity (Hoffmann, 2010; Keser et al., 2012). This study defines dependent variable as HH waste and independent variables are their socioeconomic factors. Transformation of data and various tests such as natural $\log$ transformation, heteroskedasticity and multicollinearity were conducted to ensure model robustness. Statistical analysis in this study was conducted by using data analysis and statistical software - Stata 13 .

OLS model can be expressed as:

$$
y_{i}=\beta_{0}+x_{i} \beta_{i}+\varepsilon_{i}
$$

where;

$y$ : HH waste

$x$ : HH's socioeconomic factors

$i$ : Number of observations

$\beta_{0}$ : Coefficient of intercept

$\beta_{i}$ : Parameter to be estimated

$\varepsilon$ : Error term

Empirical specification for the model can be given by:

$\mathrm{HH}$ waste $=$

$$
\begin{gathered}
\left.\left.\left.\beta_{0}+\beta_{1}(\text { gender })+\beta_{2} \text { (age }\right)+\beta_{3} \text { (education }\right)+\beta_{4}(\text { occupation })+\beta_{5}(\text { HH size })+\beta_{6} \text { (house ownership }\right)+ \\
\beta_{7}(\text { ln income })+\varepsilon
\end{gathered}
$$

where;

ln: Natural log

Heteroskedasticity causes standard errors to be biased. Thus, Breusch-Pagan/Cook-Weisberg and White's test for heteroskedasticity were used to test linear and non-linear forms of heteroskedasticity respectively. The former $\left(\operatorname{chi}^{2}(1)=152.70\right.$, Probability $\left.>\operatorname{chi}^{2}=0.0000\right)$ and the later $\left(\operatorname{chi}^{2}(32)=159.65\right.$, Probability $\left.>\operatorname{chi}^{2}=0.0000\right)$ both showed significant P-value, thus rejecting null hypothesis of homoskedasticity. To fix the problem of heteroskedasticity, we used robust standard errors. OLS assumes that errors are both independent and identically distributed; however robust standard errors reduces either or both of these assumptions and is tend to be more trustworthy (Williams, 2015). It neither changes model significance nor the coefficients, but gives relatively accurate P-values and is an effective way of dealing with heteroskedasticity (Wooldridge, 2012).

Higher degree of multicollinearity leads to regression model with unstable estimates of coefficients by wildly inflating its standard errors. One way to check for multicollinearity is through Variance Inflation Factor (VIF), the value of which should be less than 10 to conclude multicollinearity problem does not exist (Kutner, Nachtsheim, Neter, \& Li, 2004). In this case, the lowest VIF is 1.10 , highest was 1.60 , and mean was 1.32 , which proves there is no multicollinearity.

\section{Results and Discussion}

\subsection{Waste Generation}

Table 5 and Table 6 provides summary of measured variables. Study by ADB (2013) showed Gorkha municipality generated $0.14 \mathrm{~kg} / \mathrm{capita} /$ day waste, which was similar to bigger municipalities like Biratnagar SMC (Sub-Metropolitan City) $(0.14 \mathrm{~kg} / \mathrm{capita} /$ day $)$ and Birgunj SMC $(0.14 \mathrm{~kg} / \mathrm{capita} / \mathrm{day})$, but was lesser than Pokhara SMC (0.22 kg/capita/day), LSMC ( $0.19 \mathrm{~kg} /$ capita/day $)$ and KMC $(0.23 \mathrm{~kg} / \mathrm{capita} / \mathrm{day})$. On the other 
hand, this study found average $\mathrm{HH}$ waste generation of $0.85 \mathrm{~kg} /$ day and $0.24 \mathrm{~kg} / \mathrm{capita} / \mathrm{day}$, which is higher than that of KMC's, the capital city of Nepal. Bigger sample size, inclusion of all wards and weekly-based data in this study might have contributed for such discrepancy and could be considered more accurate to estimate the actual waste generation of the municipality. This range is also similar to the cities of other developing countries (Friedrich \& Trois, 2011) but much lower compared to OECD countries with generation rate of $1.43 \mathrm{~kg} / \mathrm{capita} /$ day $(\mathrm{OECD}, 2016$ ). Given the population of 39,172 inhabitants, it is estimated that 9.4 tonnes of $\mathrm{HH}$ waste per day is being generated in Gorkha municipality. It can be said that HH waste per day has increased by about 4.78 tonnes or $103.46 \%$ since 2012 (ADB, 2013) to 2015 .

Table 5. Summary of continuous variables

\begin{tabular}{llllll}
\hline Variable & Observation & Mean & $\begin{array}{l}\text { Standard } \\
\text { Deviation }\end{array}$ & Min & Max \\
\hline $\begin{array}{l}\text { HH waste (per capita } \\
\text { per day) }\end{array}$ & 401 & 0.24 & 0.10 & 0.07 & 0.81 \\
HH waste (per day) & 401 & 0.85 & 0.40 & 0.10 & 2.42 \\
Age & 401 & 47.90 & 13.07 & 23.00 & 85.00 \\
Education & 401 & 7.22 & 4.33 & 1.00 & 17.00 \\
HH size & 401 & 3.72 & 1.36 & 1.00 & 9.00 \\
Income* & 401 & 36854.20 & 28509.48 & 8020.00 & 244083.00 \\
\hline
\end{tabular}

Note. * Income is in Nepalese rupees. 1 U.S. Dollar $=102.13$ Nepalese rupees (Nepal Rastra Bank, 2017)

Table 6. Summary of categorical variables

\begin{tabular}{ll}
\hline Variable & Observation (Percentage) \\
\hline Gender: & $296(73.82)$ \\
Male & $105(26.18)$ \\
Female & \\
Occupation: & $363(90.52)$ \\
$\quad$ Employed (Businessman + Government/Private employee + Farmer) & $38(9.48)$ \\
$\quad$ Unemployed (Housewife + Retired) & \\
House ownership: & $350(87.28)$ \\
Owned & $51(12.72)$ \\
Rented &
\end{tabular}

Table 7 shows result from OLS model. R-squared value, which measures goodness of fit for estimated regression model, of 0.6356 depicts good fitting of the model. It indicates $63.56 \%$ of total variation in per day HH waste generation is accounted for by 7 included independent variables in the model.

Except for $\mathrm{HH}$ size and $\mathrm{HH}$ monthly income, other variables did not show any significant impact on HH waste generation. Both $\mathrm{HH}$ size and $\mathrm{HH}$ monthly income have positive influence on $\mathrm{HH}$ waste generation. In this case, holding all other variables constant, a member increase in $\mathrm{HH}$ will increase the total $\mathrm{HH}$ waste generation by $0.12 \mathrm{~kg} /$ day, significant at $1 \%$. Other studies have also found similar positive result (Afroz et al., 2011; Afroz, Masud, Akhtar, \& Duasa, 2013; Gu et al., 2015; Khan et al., 2016; Maskey et al., 2016; Sankoh et al., 2012; Senzige et al., 2014; Sujauddin et al., 2008; Suthar \& Singh, 2015; Trang et al., 2017). The more members in a $\mathrm{HH}$, the more will be purchased and consumed that will ultimately result in higher waste generation.

Holding all other variables constant, a percent increase in HH's monthly income will lead to generating extra waste of $0.0037 \mathrm{~kg} / \mathrm{day}$, significant at $1 \%$. This correlation has been supported by many other studies (Afroz et al., 2011; Bandara et al., 2007; Gu et al., 2015; Irwan et al., 2012; Kayode \& Omole, 2011; Maskey et al., 2016; Ogwueleka, 2013; Sankoh et al., 2012; Sujauddin et al., 2008). Higher income increases purchasing power to 
consume more, which is bound to have impact on waste generation. In an early stage of urbanization, growth in family income leads to material consumption, which increases the waste amount (Xu et al., 2016). This could also be the case in Gorkha municipality.

Table 7. OLS result after robust standard error estimation

\begin{tabular}{lllllll}
\hline HH waste & Coefficient & Robust Standard Error & $\mathrm{t}$ & $\mathrm{P}>|\mathrm{t}|$ & \multicolumn{2}{c}{$[95 \%$ Confidence Interval $]$} \\
\hline Gender & 0.0137 & 0.0292 & 0.47 & 0.639 & -0.0437 & 0.0710 \\
Age & 0.0007 & 0.0012 & 0.54 & 0.586 & -0.0017 & 0.0031 \\
Education & 0.0036 & 0.0038 & 0.96 & 0.339 & -0.0038 & 0.0110 \\
Occupation & -0.0031 & 0.0502 & -0.06 & 0.951 & -0.1018 & 0.0956 \\
HH size & $0.1169^{*}$ & 0.0133 & 8.81 & 0.000 & 0.0908 & 0.1430 \\
House ownership & 0.0316 & 0.0365 & 0.87 & 0.387 & -0.0402 & 0.1035 \\
Ln income & $0.3678^{*}$ & 0.0281 & 13.11 & 0.000 & 0.3126 & 0.4230 \\
Constant & $-3.4608^{*}$ & 0.2919 & -11.85 & 0.000 & -4.0348 & -2.8869
\end{tabular}

Note. ${ }^{a} \mathrm{Ln}$ is natural log. * significant at $1 \%$. Number of observations $=401 ;$ Probability $>\mathrm{F}=0.0000 ; \mathrm{F}(7,393)$ $=65.32 ;$ R-squared $=0.6356 ;$ Root MSE $=0.24577$

The rest of the variables did not show any significant impact on waste generation. In case of gender, as Dalen \& Halvorsen (2011) stated, there is no significant gender effects in waste generation because it is the accumulated result of all HH members' behavior. Similarly, age of HHH also has no significant impact. Although educated people are supposed to be more aware of waste impact on environment, in this case it does not have any significant impact and can be explained by the slower rate at which such awareness increases compared to rate of being educated (Oribe-Garcia et al., 2015). It can also be said that the content of education does not specifically educate or make people aware enough about waste impact on the environment to have any significant impact on their behavior. It was assumed that the kind of occupation that demands more time outside of ones' house such as being a businessman, government/private employee or farmer results in generating higher waste compared to housewives and retirees because latter would have more time to do activities that generate less waste or to manage it well. For example, they will have more time to prepare their own meal, rather than buying packaged instant food. The reason it did not show significant result could be because since people having different occupation live under the same roof, those staying-at-home members would compensate for the act/work of waste generation/management on behalf of those whose occupation demands more time outside one's house. Overall, it can be said that in case of the study area, characteristics of HHH alone does not determine waste generation as it is the outcome of combined activities of all HH members. Similarly, those who own the house also do not significantly differ than those who rent when it comes to generating more waste.

\subsection{Waste Composition}

Figure 2 provides HH waste composition of Gorkha municipality from this study. It was found that out of 343 $\mathrm{kg}$ /day waste generated by $401 \mathrm{HHs}$; organic form almost half $(47.25 \%)$, which is in line with previous studies conducted within Nepal (ADB, 2013; SWMRMC, 2004, 2008). Organic waste of developing countries in general consists of more than $50 \%$ of total waste composition (Aleluia \& Ferrão, 2016; Hoornweg \& Bhada-Tata, 2012). Table 8 provides list of waste component within each category. Organic waste included both kitchen and yard waste. Paper and paper products comprised of $10.38 \%$, followed by glass $(9.88 \%)$, metal $(6.92 \%)$, plastic $(5.39 \%)$, textile $(3.57 \%)$, and rubber and leather (1.38\%). Other waste comprised significant share of $15.23 \%$, which also included hazardous waste like batteries and light bulbs. Hazardous waste contains corrosive or toxic ingredients and are prone to catch fire, react or explode under certain circumstances. While immediate danger of such waste if disposed haphazardly may not be known, it can pollute environment and pose threat to human health if not disposed properly (United States Environmental Protection Agency (EPA), 2017). 


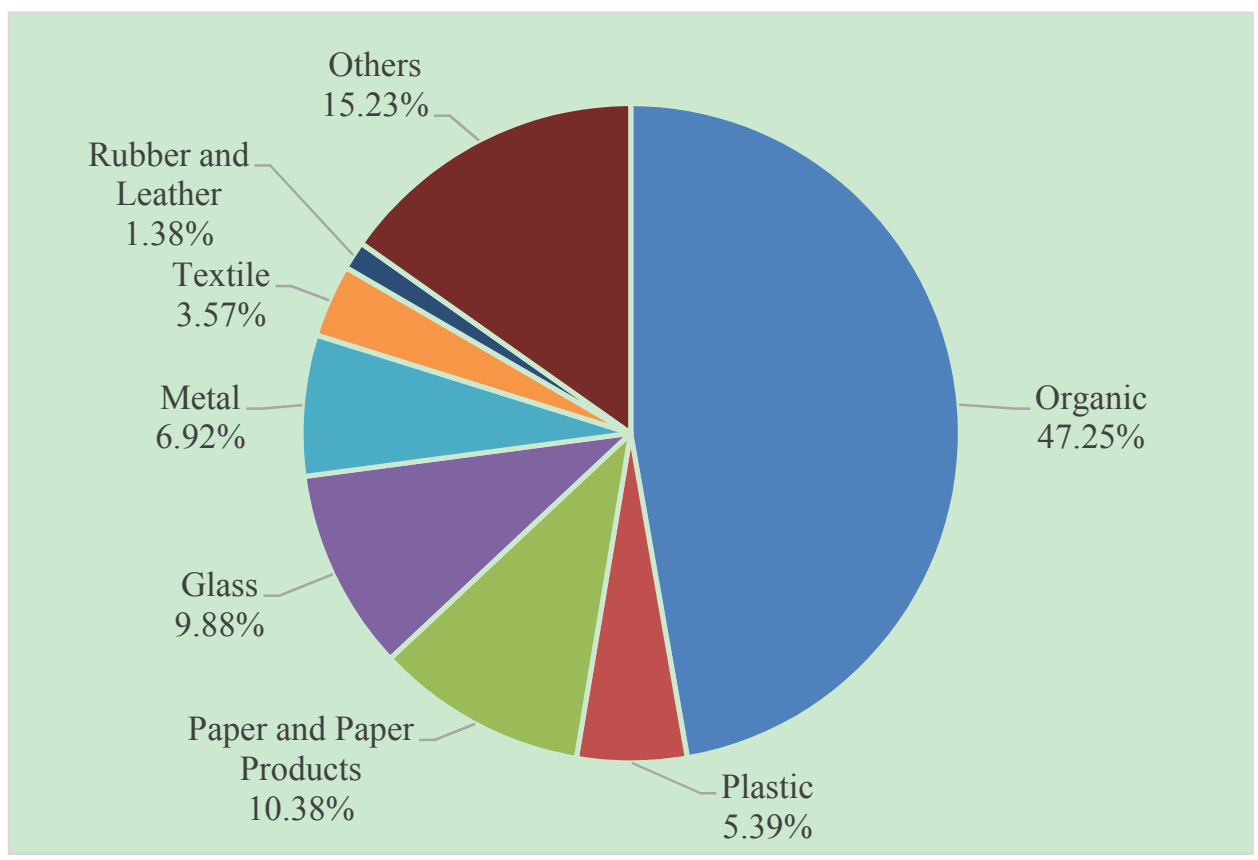

Figure 2. Waste composition of Gorkha municipality

Table 8. Description of waste component under each category

\begin{tabular}{|c|c|}
\hline Category & Description \\
\hline Organic & $\begin{array}{l}\text { kitchen waste (vegetable and fruit peelings and remains, eggshells, food leftovers/stale and } \\
\text { tainted food, tea leaves, bones, oil, etc.), yard waste (leaves, grasses, weeds, plants, flowers, } \\
\text { woods, branches, etc.) }\end{array}$ \\
\hline Metal & aluminum cans, broken construction steel rods, broken umbrella metal rods, old utensils \\
\hline $\begin{array}{l}\text { Paper and paper } \\
\text { products }\end{array}$ & notebooks, books, newspapers, cardboards \\
\hline Plastic & $\begin{array}{l}\text { Polyethylene Terephthalate bottles such as beverage bottles; Low-Density Polyethylene such } \\
\text { as trash bags and High-density polyethylene plastics such as bags and sacks, sheets, toiletries } \\
\text { containers, condiment containers, water bottles, drums, toys; and Polystyrene such as food } \\
\text { packages }\end{array}$ \\
\hline Glass & beer bottles, alcohol bottles, jars, medicine bottles \\
\hline Textile & old clothes \\
\hline Rubber and leather & slippers, shoes, belts \\
\hline Others & $\begin{array}{l}\text { ceramics, medicines, light bulbs (Compact Fluorescent, Incandescent Bulbs), batteries, } \\
\text { electronics (radios, wires), inert waste }\end{array}$ \\
\hline
\end{tabular}

At present, all these wastes are dumped in municipality designated open dumpsite where some scavengers pick up recyclable waste to sell it to junkshop owners. However, there is no data to confirm the recycling rate. If all the waste generated is to be collected and managed by the municipality, the total waste generated by HHs would be about 3,431.5 tonnes/year. Assuming $47.25 \%$ of these would be organic waste, about 1,621.4 tonnes/year of organic waste would be generated. Organic waste when decomposed in landfill or dumpsite produces methane, a major greenhouse gas (GHG) 21 times more potent than carbon dioxide (EPA, 2002). Methane emission from landfill is known to be the largest source of GHG emission from waste sector (United Nations Environment Programme [UNEP], 2010). Organic waste is also the major source for leachate production in landfill and causes unpleasant odors (Tai, Zhang, Che, \& Feng, 2011). Leachate, a fluid infiltrating from landfill generated from liquid already present in the waste or water from outside penetrating through the waste, contains various 
contaminants at concentration level impacting ground and surface water. It may be highly toxic for several decades or even centuries before reaching a level acceptable to be non-threat (Cointreau, 2006; EPA, 2002; Zorpas et al., 2015).

Thus, given the amount and intensity of its impact, organic waste should be prioritized for management. It can be managed in several ways but composting has proven to be the most economical and efficient technique among other management options in developing countries given the waste type, nature and composition (Taiwo, 2011). Composting is a natural biological degradation process where microorganisms convert organic matter into humus-like material that can be a valuable soil amendment integral to sustainable agriculture (Hoornweg, Thomas, \& Otten, 2000). But it is also a matter of who should take responsibility of composting as it can be done at $\mathrm{HH}$, community or institutional level. From key informant interview it was found that out of 15 wards, municipality provides waste collection service to only 6 wards which even today is done with the possession of only one tractor. Overall collection efficiency is estimated to be about $30 \%$ only (ADB, 2013). This lack of capacity proves that majority of organic waste still gets left behind uncollected. Composting organic waste at source is known to be the best way of solid waste disposal as it will reduce the waste volume transported to the landfill and will increase landfill's life (Pokhrel \& Viraraghavan, 2005). It thus favors HHs, the main source of waste generation, to compost so that it reduces amount of waste that needs to be collected and managed, decreasing the overall cost of SWM.

From the follow-up survey of HHs who were provided subsidized compost bin by the local government, only about $56 \%$ of them are found to be continuing to use compost bin and the rest $44 \%$ are not using either because of insect invasion, bad smell, leachate generation, lack of space, lack of waste as input, lack of expertise in making quality compost, damaged bin or simply because they could not invest enough time. All this could also be because HHs do not realize the economic benefit of using compost. While supporting HHs through follow-up training can increase the adoption rate to certain extent, there is bound to be some who will not prefer composting on their own. That is why municipality should take their own initiative of composting as well. Another way is to assign duties at the ward-level where material recovery and composting facilities can be built. This method has proven to be very successful in lessening waste generation and improving waste management process in developing country like the Philippines (Maskey et al., 2016). Smaller administrative units like wards would be more efficient in collecting and handling waste given proper resources are available.

Composting requires organic waste to be separated from other waste, which makes it easier to collect other recyclable waste as well. Source separation of waste is important to reduce waste treatment cost (Pokhrel \& Viraraghavan, 2005). According to Tai et al. (2011), because of lack of kitchen waste separation, municipal recycling system receives $60 \%$ of food remnants, thus causing MSW to be of low calorific value, high moisture content and high proportion of organisms with low average net heating value. Therefore, waste segregation should be encouraged at least in two categories: organic and non-organic. From the follow-up interview while collecting one week segregated waste, it was revealed that $91 \%$ of respondents are willing to segregate waste in the future, which can be trustworthy as they just had first-hand experience of waste segregation. The reasons were for cleaner environment and self-satisfaction on being part of a good waste management practice that stimulated recycling.

Since this survey is conducted on just $401 \mathrm{HHs}$, local government should examine and encourage all HHs through environmental education, and training and awareness programs that will gradually instill value, followed by action. Public education on MSW source-separated collection through various media such as radio, television, newspaper and internet have helped increase residents' awareness (75\%) and their behavior (50\%); but it should also be supported with required facility as inadequate number of classified containers in residential areas have led to poor source-separated collection rate (18\%) (Tai et al., 2011).

Recyclables including metal, paper, plastics, glass, textiles, and rubber and leather also comprised of about $37.52 \%$ of $\mathrm{HH}$ waste, which totals to be about 1,287.5 tonnes/year. There is no recycling institution within the municipality itself, but the scavengers or waste pickers collect recyclable waste from dumpsite and sell them to junkshop owners who are responsible for transporting such materials to cities where recycling exists. While there is no formal data as to how much waste is being diverted by recycling, institutionalizing the current waste pickers in addition to enforcing waste segregation would lead to better diversion of recyclable waste. This might also increase local job opportunity of recyclable waste collection and transportation. Other waste formed about 522.6 tonnes/year, which also includes hazardous waste. Unfortunately, municipality does not have any separate system to collect and manage hazardous waste but is amassed together with other municipal waste and is disposed at the dumpsite. There should be an arrangement for managing especially the hazardous waste to the highest possible environmentally and socially acceptable standards. It is also worth mentioning that if waste 
from other sources such as commercial, industrial or institutional entities were to be included, the total waste that is actually generated in each of the category would be much higher and most probably ends up being uncollected or disposed at the open dumpsite.

\section{Conclusion and Recommendations}

Like any other cities in developing countries, Gorkha municipality of Nepal is marred by growing amount of municipal solid waste but is severely devoid of required resources and reliable data to make an effective waste management strategy. To the best of our knowledge, this study is the first in Gorkha municipality to assess correlation of relevant socioeconomic factors affecting $\mathrm{HH}$ waste generation. Socioeconomic factors are an important indicator in behavioral studies and HHs were focused among other categories of waste generators because in Nepal they are responsible for about $75 \%$ of total municipal waste generation. Perhaps one of the most important aspects of this study that strengthens the accuracy of its result is that it relied on bigger sample size, included all municipality wards and collected weekly instead of just one-day data on waste generation as was done by previous studies. Among the socioeconomic factors, this study found that family size and income are important indicators to forecast solid waste generation trend.

Meanwhile, focus should also be on waste management strategy. While analyzing waste composition, organic waste formed the highest share of total waste. From this study, it is estimated that in Gorkha municipality, HHs generate about 1,621.4 tonnes of organic waste every year, most of which are uncollected and the rest discarded in an open dumpsite. If left unattended, it will create problems of smell, leachate, flies, rodents and methane emission that will affect human health and environment. Thus, given the amount and intensity of its impact, organic waste should be prioritized for management. It can be managed in several ways but composting has proven to be the most economical and efficient technique among other management options in developing countries given the waste type, nature and composition. The best strategy would have been to promote $\mathrm{HH}$ composting as managing at source would lead to environmentally sound and economically feasible means, but most importantly it reduces waste volume that needs to be transported to the dumpsite, which municipality is already incapable of. However, follow-up survey found that the success rate of $\mathrm{HH}$ composting has proven to be just $56 \%$ even after providing training and distributing subsidized compost bins by the municipality. While supporting HHs through follow-up training shall increase the adoption rate to certain extent, there is bound to be some who will not prefer composting on their own. That is why municipality should take their own initiative of composting as well. Another way is to assign duties at the ward-level so that collection and handling of waste would be more efficient with proper resources in place.

The recyclable potential of remaining waste (metal, paper, plastic, glass, textiles, and rubber and leather) is also very high $(37.52 \%$ of total waste or about $1,287.5$ tonnes/year). Even though there is no recycling institution within the municipality, the current waste pickers who collect recyclable waste from landfill should be institutionalized in order to effectively channel recyclable waste to junkshop owners who are responsible for transporting these materials in cities where recycling exists. This might also increase local job opportunity of recyclable waste collection and transportation. Other waste formed $15.23 \%$ of total waste (about 522.6 tonnes/year) which is of significant amount as well and should be managed accordingly. It includes hazardous waste as well, which should be managed in the highest possible environmentally and socially acceptable standards as it contains corrosive or toxic ingredients that pollute environment and pose threat to human health. If waste from other sources such as commercial, industrial or institutional entities were to be included, the total waste generated in the municipality would be much higher.

In the midst of waste management, waste segregation should be the most important step that assures waste management in an environmentally sound and economically feasible way. HHs should be encouraged to segregate waste at least in two categories: organic and non-organic. It was revealed that $91 \%$ of respondents are willing to segregate waste in the future, which can be trustworthy as they just had first-hand experience of waste segregation in the process of taking part in this study. The local government should encourage all HHs through environmental education, and training and awareness programs that will gradually instill value, followed by action.

\section{Acknowledgements}

We are very grateful to staffs of Gorkha municipality for their insightful information and support for this study. We would like to thank all the enumerators who assisted in conducting fieldwork in all the wards of the municipality. Sincere appreciation also goes to all respondents for their valuable time. 


\section{References}

Adeniran, A. E., Nubi, A. T., \& Adelopo, A. O. (2017). Solid waste generation and characterization in the University of Lagos for a sustainable waste management. Waste Management, 67, 3-10. https://doi.org/10.1016/j.wasman.2017.05.002

Afroz, R., Hanaki, K., \& Tudin, R. (2011). Factors affecting waste generation: A study in a waste management program in Dhaka City, Bangladesh. Environmental Monitoring and Assessment, 179(1-4), 509-519. https://doi.org/10.1007/s10661-010-1753-4

Afroz, R., Masud, M. M., Akhtar, R., \& Duasa, J. B. (2013). Survey and analysis of public knowledge, awareness and willingness to pay in Kuala Lumpur, Malaysia - A case study on household WEEE management. Journal of Cleaner Production, 52, 185-193. https://doi.org/10.1016/j.jclepro.2013.02.004

Alam, R., Chowdhury, M. A. I., Hasan, G. M. J., Karanjit, B., \& Shrestha, L. R. (2008). Generation, storage, collection and transportation of municipal solid waste - A case study in the city of Kathmandu, capital of Nepal. Waste Management, 28(6), 1088-1097. https://doi.org/10.1016/j.wasman.2006.12.024

Aleluia, J., \& Ferrão, P. (2016). Characterization of urban waste management practices in developing Asian countries: A new analytical framework based on waste characteristics and urban dimension. Waste Management, 58, 415-429. https://doi.org/10.1016/j.wasman.2016.05.008

Armijo de Vega, C., Ojeda Benítez, S., \& Ramírez Barreto, M. E. (2008). Solid waste characterization and recycling potential for a university campus. Waste Management, 28(Supplement 1), S21-S26. https://doi.org/10.1016/j.wasman.2008.03.022

Asian Development Bank [ADB]. (2013). Solid waste management in Nepal: Current status and policy recommendations. Mandaluyong City, Philippines: Asian Development Bank. Retrieved from https://www.adb.org/sites/default/files/publication/30366/solid-waste-management-nepal.pdf

Baker, S. (1997). Community organization and solid waste management in the Kathmandu Valley. Himalaya, the Journal of the Association for Nepal and Himalayan Studies, 17(1).

Bandara, N. J. G. J., Hettiaratchi, J. P. A., Wirasinghe, S. C., \& Pilapiiya, S. (2007). Relation of waste generation and composition to socio-economic factors: A case study. Environmental Monitoring and Assessment, 135(13), 31-39. https://doi.org/10.1007/s10661-007-9705-3

Central Bureau of Statistics [CBS]. (2014a). National population and housing census 2011: Urban tables (Vol. 07, Part I). Kathmandu, Nepal: Central Bureau of Statistics.

Central Bureau of Statistics [CBS]. (2014b). Population monograph of Nepal (Vol. III). Kathmandu, Nepal: Central Bureau of Statistics. Retrieved from http://cbs.gov.np/image/data/Population/Population Monograph of Nepal 2014/Population Monograph V03.pdf

Cointreau, S. (2006). Occupational and environmental health issues of solid waste management: Special emphasis on middle- and lower-income countries. Urban Papers. Washington, DC: The World Bank.

Dahlén, L., \& Lagerkvist, A. (2008). Methods for household waste composition studies. Waste Management, 28(7), 1100-1112. https://doi.org/10.1016/j.wasman.2007.08.014

Dalen, H. M., \& Halvorsen, B. (2011). Gender differences in environmental related behaviour. Statistics Norway. Retrieved from https://www.ssb.no/a/english/publikasjoner/pdf/rapp_201138_en/rapp_201138_en.pdf

Dangi, M. B., Pretz, C. R., Urynowicz, M. A., Gerow, K. G., \& Reddy, J. M. (2011). Municipal solid waste generation in Kathmandu, Nepal. Journal of Environmental Management, 92(1), 240-249. https://doi.org/10.1016/j.jenvman.2010.09.005

Devkota, D. C., Watanabe, K., \& Dangol, V. (2004). Need for alternative approaches in solid waste management Case study Kathmandu Valley. In 30th WEDC International Conference (pp. 79-82). Vientiane, Lao PDR.

Duwal, I. (2015). Integrated sustainable waste management in Bhaktapur, Nepal: A case study of current practices regarding waste separation and spatial issues related with municipal solid waste management in Bhaktapur, Nepal. Wageningen University, Wageningen, The Netherlands.

Edjabou, M. E., Jensen, M. B., Götze, R., Pivnenko, K., Petersen, C., Scheutz, C., \& Astrup, T. F. (2015). Municipal solid waste composition: Sampling methodology, statistical analyses, and case study evaluation. Waste Management, 36, 12-23. https://doi.org/10.1016/j.wasman.2014.11.009

Friedrich, E., \& Trois, C. (2011). Quantification of greenhouse gas emissions from waste management processes for municipalities - A comparative review focusing on Africa. Waste Management, 31(7), 1585-1596. 
https://doi.org/10.1016/j.wasman.2011.02.028

Gallardo, A., Edo-Alcón, N., Carlos, M., \& Renau, M. (2016). The determination of waste generation and composition as an essential tool to improve the waste management plan of a university. Waste Management, 53, 3-11. https://doi.org/10.1016/j.wasman.2016.04.013

Gorkha Municipality Office. (2015). नगर विकाश योजना २०७२ (Municipal development plan 2072) (Vol. 6). गोरखा नगरपालिका कार्यालय (Gorkha Municipality Office). Retrieved from http://gorkhamun.gov.np/sites/gorkhamun.gov.np/files/documents/Gorkha books $2072 \% 282 \% 29$.pdf. [In Nepali]

Gu, B., Wang, H., Chen, Z., Jiang, S., Zhu, W., Liu, M., ... Bi, J. (2015). Characterization, quantification and management of household solid waste: A case study in China. Resources, Conservation and Recycling, 98, 67-75. https://doi.org/10.1016/j.resconrec.2015.03.001

Hoffmann, J. P. (2010). Linear regression analysis: Assumptions and applications (Second). Provo: Brigham Young University.

Hoornweg, D., \& Bhada-Tata, P. (2012). What a waste: A global review of solid waste management (Urban Development Series No. 15).

Hoornweg, D., Thomas, L., \& Otten, L. (2000). Composting and its applicability in developing countries (No. 8). Urban Waste Management.

Irwan, D., Basri, N. E. ., \& Watanabe, K. (2012). Interrelationship between affluence and household size on municipal solid waste arising: Evidence from selected residential areas of Putrajaya. Journal of Asian Scientific Research, 2(11), 747-758. Retrieved from http://aessweb.com/journal-detail.php?id=5003

Japan International Cooperation Agency [JICA]. (2005). The study on the solid waste management for the Kathmandu valley (Vol. II). Japan International Cooperation Agency.

Kawai, K., \& Tasaki, T. (2016). Revisiting estimates of municipal solid waste generation per capita and their reliability. Journal of Material Cycles and Waste Management, 18(1), 1-13. https://doi.org/10.1007/s10163-015-0355-1

Kayode, A. M., \& Omole, F. K. (2011). Some socio-economic factors affecting solid wastes generation and disposal in Ibadan Metropolis, Nigeria. Journal of Environmental Issues and Agriculture in Developing Countries, 3(1), 55-64.

Keser, S., Duzgun, S., \& Aksoy, A. (2012). Application of spatial and non-spatial data analysis in determination of the factors that impact municipal solid waste generation rates in Turkey. Waste Management, 32(3), 359-371. https://doi.org/10.1016/j.wasman.2011.10.017

Khan, D., Kumar, A., \& Samadder, S. R. (2016). Impact of socioeconomic status on municipal solid waste generation rate. Waste Management, 49, 15-25. https://doi.org/10.1016/j.wasman.2016.01.019

Kutner, M. H., Nachtsheim, C. J., Neter, J., \& Li, W. (2004). Applied linear statistical models (5th ed.). New York: McGraw-Hill/Irwin.

Lebersorger, S., \& Beigl, P. (2011). Municipal solid waste generation in municipalities: Quantifying impacts of household structure, commercial waste and domestic fuel. Waste Management, 31(9-10), 1907-1915. https://doi.org/10.1016/j.wasman.2011.05.016

Local Governance and Community Development Programme [LGCDP]. (2016). 58 Old Municipality GIS Map. Retrieved July 17, 2016, from http://lgcdp.gov.np/gis_58mun?page=1

Marshall, R. E., \& Farahbakhsh, K. (2013). Systems approaches to integrated solid waste management in developing countries. Waste Management, 33(4), 988-1003. https://doi.org/10.1016/j.wasman.2012.12.023

Maskey, B., Maharjan, K. L., \& Singh, M. (2016). Ecological solid waste management act and factors influencing solid waste management in barangay Pansol of Quezon City, the Philippines. Journal of International Development and Cooperation, 22, 37-45.

Miezah, K., Obiri-Danso, K., Kádár, Z., Fei-Baffoe, B., \& Mensah, M. Y. (2015). Municipal solid waste characterization and quantification as a measure towards effective waste management in Ghana. Waste Management, 46, 15-27. https://doi.org/10.1016/j.wasman.2015.09.009

Nepal Rastra Bank. (2017). Foreign exchange rates. Retrieved September 1, 2016, from https://www.nrb.org.np/fxmexchangerate.php?YY=2017\&MM=08\&DD=31\&B1=Go 
Ogwueleka, T. C. (2013). Survey of household waste composition and quantities in Abuja, Nigeria. Resources, Conservation and Recycling, 77, 52-60. https://doi.org/10.1016/j.resconrec.2013.05.011

Ojeda-Benítez, S., Vega, C. A., \& Marquez-Montenegro, M. Y. (2008). Household solid waste characterization by family socioeconomic profile as unit of analysis. Resources, Conservation and Recycling, 52(7), 992-999. https://doi.org/10.1016/j.resconrec.2008.03.004

Organisation for Economic Co-operation and Development [OECD]. (2014). Greening household behaviour: Overview from the 2011 survey - Revised edition (OECD Studies on Environmental Policy and Household Behaviour). Paris: OECD Publishing. https://doi.org/10.1787/9789264214651-en

Organisation for Economic Co-operation and Development [OECD]. (2016). Municipal waste. In OECD factbook 2015-2016: Economic, environmental and social statistics (pp. 142-143). Paris: OECD Publishing. https://doi.org/http://dx.doi.org/10.1787/factbook-2015-en

Organization for Security and Co-operation in Europe [OSCE]. (2009). Gender and environment: A guide to the integration of gender aspects in the OSCE'S environmental projects. Vienna: OSCE. Retrieved from https://www.google.fi/url?sa=t\&rct=j\&q=\&esrc=s\&source=web\&cd=1\&ved=0ahUKEwjms6WYjM3NAh VSSZoKHRyOBuUQFggfMAA\&url=http\%3A\%2F\%2Fwww.osce.org\%2Fgender\%2F36360\%3Fdownloa d\%3Dtrue\&usg=AFQjCNGJii5XuGIfmDSZhZr9TP0_vIoBpA\&sig2=uarPBTcQiLgYFKNpYillnw\&bvm= bv. 12580152

Oribe-Garcia, I., Kamara-Esteban, O., Martin, C., Macarulla-Arenaza, A. M., \& Alonso-Vicario, A. (2015). Identification of influencing municipal characteristics regarding household waste generation and their forecasting ability in Biscay. Waste Management, 39, 26-34. https://doi.org/10.1016/j.wasman.2015.02.017

Padeco Co. Ltd., \& Consultants, M. (2010). Volume 3: Solid waste management. Nepal: Preparing the secondary towns integrated urban environmental improvement project (Vol. 3). Asian Development Bank. Retrieved from https://www.adb.org/sites/default/files/project-document/67548/36188-01-nep-tacr-03.pdf

Palanivel, T. M., \& Sulaiman, H. (2014). Generation and composition of municipal solid waste (MSW) in Muscat, Sultanate of Oman. APCBEE Procedia, 10, 96-102. https://doi.org/10.1016/j.apcbee.2014.10.024

Pfammatter, R., \& Schertenleib, R. (1996). Non-governmental refuse collection in low-income urban areas: Lessons learned from selected schemes in Asia, Africa and Latin America. Sandec Report No. 1/96. Duebendorf, Switzerland: Swiss Federal Institute for Environmental Science and Technology.

Pokhrel, D., \& Viraraghavan, T. (2005). Municipal solid waste management in Nepal: Practices and challenges. Waste Management, 25(5), 555-562. https://doi.org/10.1016/j.wasman.2005.01.020

Practical Action Nepal. (2008). Best practices on solid waste management of Nepalese cities. Kathmandu, Nepal: Practical Action Nepal.

Premakumara, D. G. J. (2013). Community-based solid waste management system in Saankhu city, Nepal.

Qu, X., Li, Z., Xie, X., Sui, Y., Yang, L., \& Chen, Y. (2009). Survey of composition and generation rate of household wastes in Beijing, China. Waste Management, 29(10), 2618-2624. https://doi.org/10.1016/j.wasman.2009.05.014

Ranabhat, R. (2015). Life cycle assessment of municipal solid waste management system in Kathmandu, Nepal. Journal of Advanced College of Engineering and Management, 1 .

Sankoh, F. P., Yan, X., \& Conteh, A. M. H. (2012). A situational assessment of socioeconomic factors affecting solid waste generation and composition in Freetown, Sierra Leone. Journal of Environmental Protection, 3, 563-568. https://doi.org/10.4236/jep.2012.37067

Senzige, J. P., Makinde, D. O., Njau, K. N., \& Nkansah-Gyeke, Y. (2014). Factors influencing solid waste generation and composition in urban areas of Tanzania: The case of Dar-es-Salaam. American Journal of Environmental Protection, 3(4), 172-178. https://doi.org/10.11648/j.ajep.20140304.11

Shrestha, M. E. I., Sartohadi, J., Ridwan, M. K., \& Hizbaron, D. R. (2014). Converting urban waste into energy in Kathmandu Valley: Barriers and opportunities. Journal of Environmental Protection, 5, 772-779. https://doi.org/10.4236/jep.2014.59079

Shrestha, S. L. (2015). Final report on implementation of solid waste management plan in Sankhu city.

Singh, R. K., Yabar, H., Mizunoya, T., Higano, Y., \& Rakwal, R. (2014). Potential benefits of introducing integrated solid waste management approach in developing countries: A case study in Kathmandu city. Journal of Sustainable Development, 7(6), 70-83. https://doi.org/10.5539/jsd.v7n6p70 
Society for Environment and Economic Development Nepal [SEED Nepal]. (2009). Baseline study report on assessment of current waste agricultural biomass management system and practices at national and local level at Madhyapur Thimi municipality. Kathmandu, Nepal.

Solid Waste Management and Resource Mobilization Center [SWMRMC]. (2004). A diagnostic report on state of solid waste management in municipalities of Nepal. Kathmandu, Nepal: SWMRMC.

Solid Waste Management and Resource Mobilization Center [SWMRMC]. (2008). Baseline study on solid waste management in municipalities of Nepal. Kathmandu, Nepal: SWMRMC.

Soukopová, J., Struk, M., \& Hřebíček, J. (2016). Population age structure and the cost of municipal waste collection. A case study from the Czech Republic. Journal of Environmental Management, 1-9. https://doi.org/10.1016/j.jenvman.2016.03.030

Sujauddin, M., Huda, S. M. S., \& Hoque, A. T. M. R. (2008). Household solid waste characteristics and management in Chittagong, Bangladesh. Waste Management, 28(9), 1688-1695. https://doi.org/10.1016/j.wasman.2007.06.013

Suthar, S., \& Singh, P. (2015). Household solid waste generation and composition in different family size and socio-economic groups: A case study. Sustainable Cities and Society, 14(1), 56-63. https://doi.org/10.1016/j.scs.2014.07.004

Tai, J., Zhang, W., Che, Y., \& Feng, D. (2011). Municipal solid waste source-separated collection in China: A comparative analysis. Waste Management, 31(8), 1673-1682. https://doi.org/10.1016/j.wasman.2011.03.014

Taiwo, A. M. (2011). Composting as a sustainable waste management technique in developing countries. Journal of Environmental Science and Technology, 4(2), 93-102. https://doi.org/10.3923/jest.2011.93.102

Thapa, G. B. (1998). Lessons learned from solid waste management in Kathmandu, Nepal. Habitat International, 22(2), 97-114. https://doi.org/10.1016/S0197-3975(97)00030-1

The World Bank. (2017). GDP (current US\$). Retrieved August 7, 2017, from https://data.worldbank.org/indicator/NY.GDP.MKTP.CD?locations=NP\&view=chart

Trang, P. T. T., Dong, H. Q., Toan, D. Q., Hanh, N. T. X., \& Thu, N. T. (2017). The effects of socio-economic factors on household solid waste generation and composition: A case study in Thu Dau Mot, Vietnam. Energy Procedia, 107, 253-258. https://doi.org/10.1016/j.egypro.2016.12.144

United Nations Environment Programme [UNEP]. (2010). Waste and climate change: Global trends and strategy framework. Japan: UNEP.

United States Environmental Protection Agency (EPA). (2017). Household Hazardous Waste (HHW). Retrieved September 1, 2017, from https://www.epa.gov/hw/household-hazardous-waste-hhw

United States Environmental Protection Agency [EPA]. (2002). Solid waste management: A local challenge with global impacts. Washington, DC, U.S.A. Retrieved from http://www.epa.gov/osw/nonhaz/municipal/pubs/ghg/f02026.pdf

Williams, R. (2015). Heteroskedasticity. Retrieved July 15, 2016, from https://www3.nd.edu/ rwilliam/stats2/125.pdf

Wooldridge, J. M. (2012). Introductory econometrics: A modern approach (5th ed.). Mason, USA: Cengage Learning.

Xu, L., Lin, T., Xu, Y., Xiao, L., Ye, Z., \& Cui, S. (2016). Path analysis of factors influencing household solid waste generation: A case study of Xiamen Island, China. Journal of Material Cycles and Waste Management, 18(2), 377-384. https://doi.org/10.1007/s10163-014-0340-0

Yamane, T. (1967). Statistics: An introductory analysis (2nd ed.). New York: Harper and Row.

Zorpas, A. A., Lasaridi, K., Voukkali, I., Loizia, P., \& Chroni, C. (2015). Household waste compositional analysis variation from insular communities in the framework of waste prevention strategy plans. Waste Management, 38(1), 3-11. https://doi.org/10.1016/j.wasman.2015.01.030

\section{Copyrights}

Copyright for this article is retained by the author(s), with first publication rights granted to the journal.

This is an open-access article distributed under the terms and conditions of the Creative Commons Attribution license (http://creativecommons.org/licenses/by/4.0/). 